\title{
PENGGUNAAN MODEL PEMBELAJARAN GLASER DALAM MENINGKATKAN MINAT BELAJAR DI KELAS VIII MTS MUHAMMADIYAH 22 PADANGSIDIMPUAN TAHUN PELAJARAN 2018-2019
}

\author{
Ahmad Husein Nasution 1), Delima Lubis, ${ }^{2)}$ \\ 1, FKIP - Prodi PKn Universitas Muhammadiyah Tapanuli Selatan \\ 2) FKIP - Prodi Pendidikan Ekonomi Universitas Muhammadiyah Tapanuli Selatan
}

\begin{abstract}
Abstrak
Tujuan penelitian ini adalah untuk mengetahui keefektifitasan model pembelajaran Glaser pada bidang studi pendidikan kewarganegaraan dan untuk mengetahui minat belajar peserta didik pada bidang studi pendidikan kewarganegaraan.Berdasarkan analisa data di atas, maka diperoleh nilai $r_{x y}$ hitung $=0,993$ Selanjutnya penulis menetapkan nilai $\mathrm{r}_{\mathrm{xy}}$ tabel pada taraf kesalahan $5 \%$ dengan $\mathrm{N}=34$ orang peserta didik adalah 0,339, dan taraf kesalahan $1 \%$ adalah 0,436 (lihat daftar tabel terlampir). Untuk menguji kebenaran hipotesis dilakukan dengan ketentuan untuk melihat pengaruh nilai $r_{x y}$ hitung dengan $r_{x y}$ tabel, dimana apabila nilai $r_{x y}$ hitung lebih besar dari $r_{x y}$ tabel maka hipotesis alternatif (Ha) diterima kebenarannya ekefektivitas model pembelajaran glaser terhadap minat belajar peserta didik pada bidang studi pendidikan kewarganegaraan (PKn) dan $\mathrm{H}_{0}$ ditolak, dan sebaliknya apabila nilai $\mathrm{r}_{\mathrm{xy}}$ hitung lebih kecil dari $\mathrm{r}_{\mathrm{xy}}$ tabel, maka $\mathrm{H}_{\mathrm{o}}$ diterima dan $\mathrm{Ha}$ ditolak kebenarannya yaitu tidak ada peran guru secara psikologis terhadap minat belajar peserta didik dengan materi pokok hakikat demokrasi dan macam-macam demokrasi pada bidang studi Pendidikan Kewarganegaraan.
\end{abstract}

Kata Kunci: Pembelajaran, Glaser, Dalam, Meningkatkan, Minat, Belajar

*Correspondence Address : ahmadhusein735@gmail.co.id DOI : $10.31604 /$ jips.v6i2.2019.233-237

(C) 2019 Fakultas Keguruan \& Ilmu Pendidikan UM-Tapanuli Selatan 


\section{A. Pendahuluan}

Beberapa model pembelajaran yang dikembangkan oleh para ahli untuk melaksanakan model Pembelajaran. Model-model tersebut cukup bervariasi, namun dari kesemuanya dapat ditarik kesimpulan mengenai persamaannya sehubungan dengan pengambilan keputusan sebagai pemanfaatan data pelaksanaan model pembelajaran. Beberapa evaluator mengikuti satu pola tertentu akan tetapi beberapa diantaranya telah menggabungkan model-model tersebut, dan sebagian lainnya tetap menggunakan model yang tradisional seperti model pembelajaran.

Mengajar adalah membelajarkan para peserta didik, mengajar adalah memfasilitasi para peserta didik untuk giat belajar, mendorong mereka untuk mengeksplorasi bahan pembelajaran. Dengan demikian, mengajar dapat disimpulkan dengan sebuah pekerjaan yang dinamis, berbasis sebuah perencanaan tetapi memiliki peluang untuk merubah seseorang dari yang awalnya tidak mengerti menjadi mengerti.

Undang-undang pendidikan sebagai salah satu dasar hukum dalam negara Indonesia dan telah mengatur standar nasional pendidikan yang harus ditempuh oleh sekolah. Yang kemudian diperjelas oleh Keputusan Menteri Pendidikan Kependidikan dan Kebudayaan dalam hal ini yang mengatur tentang pengembangan proses pembelajaran khusus mata pelajaran Pendidikan Kewarganegaraan di tingkat sekolah lanjutan tingkat atas dan sederajat.

\section{Pendidikan Kewarganegaraan} merupakan bagian pendidikan secara keseluruhan dan pendidikan kewarganegaraan mempunyai kedudukan yang sangat penting karena Pendidikan Kewarganegaraan merupakan pengetahuan dasar yang berhubungan langsung dengan ilmu pengetahuan dan teknologi (IPTEK) dalam kehidupan sehari-hari. Pendidikan Kewarganegaraan juga mempunyai kedudukan sebagai pembantu cabang-cabang ilmu pengetahuan lain yang memerlukan perhitungan, seperti agama, sosiologi, sejarah, kebudayaan, Ekonomi dan lain sebagainya

\section{METODE PENELITIAN}

Dalam penelitian ini penulis adalah penelitian asosiatif yaitu membandingkan dua variabel. Variabelvariabel dalam penelitian ini yaitu : 
1. Variabel X adalah efektifitas penggunaan model pembelajaran Glaser

2. Variabel $Y$ adalah minat belajar peserta didik pada bidang studi pendidikan kewarganegaraan di kelas VIII MTs Muhammadiyah 22 Padangsidimpuan Tahun Pelajaran 2018-2019.

\section{HASIL DAN PEMBAHASAN}

Berdasarkan penyebaran angket yang dilakukan di kelas VIII MTs Muhammadiyah 22 Padangsidimpuan Tahun Pelajaran 2018-2019 dengan deskripsi data sebagai berikut:

Data yang diperoleh berdasarkan angket yang disebarkan kepada responden atau sebagai sampel penelitian dengan penyebaran angket tentang penggunaan model pembelajaran galser dengan kriteria jawaban

Untuk mengetahui besarnya persentase angket respon peserta didik. Dari rekapitulasi pengunaan model pembelajaran glaser menunjukkan bahwa yang memilih option "A" adalah sebanyak 95,88 \% dan peserta didik yang memilih option "B " adalah sebanyak 4,12 \% sedangakn untuk option "C" tidak ada yang memilih. Sehingga berdasarkan rekapitulasi di atas menunjukkan bahwa lebih banyak peserta didik memilih option " $A$ ".

Setelah diperoleh data perolehan secara persentase dari penggunaan model pembelajaran Glaser kemudian angket yang disebarkan kepada peserta didik diberi skor nilai masing-masing perbutir soal dengan nilai 10 apabila peserta didik menjawab dengan betul sedangkan jawaban peserta didik salah diberikan nilai 0 .

Berdasarkan data diatas, maka dapat diketahui nilai rata-rata jawaban peserta didik terhadap angket penggunaan model pembelajaran glaser untuk variabel $\mathrm{X}$ adalah sebagai berikut :

$$
\begin{aligned}
& X=\frac{\sum X}{N} \quad X=\frac{3120}{34} \quad X=91,76 \\
& Y=\frac{\sum Y}{N} Y=\frac{3240}{34} \\
& Y=95,29
\end{aligned}
$$

Berdasarkan hasil analisa angket penelitian tersebut diatas diperoleh nilai rata-rata jawaban peserta didik adalah 95,29 .

Berdasarkan hasil analisa angket penelitian tersebut diatas diperoleh nilai rata-rata jawaban peserta didik adalah 91,76 . 
Setelah dilakukan penyebaran angket tentang penggunaan model pembelajaran glaser kemudian penulis melakukan analisa terhadap minat belajar peserta didik dengan materi pokok hakikat demokrasi dan macammacam demokrasi. Berdasarkan rekapitulasi dari minat belajar peserta dengan materi pokok hakikat demokrasi dan macam-macam demokrasi disimpulkan bahwa peserta didik yang memilih option "A" adalah 91,76\% dan memilih option "B" adalah 5,59 \% sedangkan untuk memilih option " $\mathrm{C}$ " sebanyak 2,65 \%. Dari perhitungan dari keseluruhan menunjukkan bahwa yang paling banyak yang dipilih oleh peserta didik adalah jawaban option "A" sebanayak 91,76\%.

\section{SIMPULAN}

Berdasarkan ketentuan tersebut maka dapat dilihat bahwa nilai $r_{x y}$ hitung lebih besar dengan $r_{x y}$ tabel dengan taraf kesalahan $5 \%$ atau $1 \%(0,339$ - 0,436 > 0,993), berdasarkan hasil ini dapat disimpulkan bahwa Ha dapat diterima kebenarannya dengan ada efektivitas model pembelajaran glaser terhadap minat belajar peserta didik pada bidang studi pendidikan kewarganegaraan (PKn) dengan materi pokok hakikat demokrasi dan macam-macam demokrasi di kelas VIII MTs
Muhammadiyah 22 Padangsidimpuan Tahun Pelajaran 2018-2019.

\section{Daftar Pustaka}

Arikunto Suharsimi, 2007 Prosedur Penelitian Suatu Pendekatan Praktik, Jakarta: Rineka Cipta

PT.Rineka cipta. Jakarta

Azwar Saifuddin,2010, Metode Penelitian, Yogyakarta: Pustaka Pelajar Offset

Browmn Goerge, 2005, Pengajaran Mikro: Program ketrampilan mengajar, Surabaya: Airlangga University Press

Departemen Pendidikan Nasional, 2005, Kamus Bahasa Indonesia, Balai Pustaka

Dimyati dan Mudjiono, 2005, Belajar dan Pembelajaran, Jakarta PT Rineka Cipta

Faisal Sanafiah, 2005, Prosedur Penelitian, Bandung Tarsito

Gaffar Affan, 2005, Politk Indonesia Transisi Menuju Demokrasi, Yogyakarta: Pustaka Pelajar

Gulo.W, 2005, Metodologi Penelitian, Jakarta: PT. Gramedia

Hamid Abdul, 2009, Teori Belajar dan Pembelajaran, Jakarta Grafindo

Mulyani Sumantri dan Nana Syaodih. 2009, Perkembangan Peserta Didik. Jakarta: Universitas Terbuka

Muh. Usman User,2007, Kiat Pembelajaran Siswa, Jakarta Gaung Persada Pers

Martinus Yamin, 2007, Kiat Membelajarkan Siswa, PT Gaung Persada Pers

Nasuiton.S, 2006, Didaktik Azas-Azas Mengajar, Bandung Jemmar

Rusman, 2012, Model-model Pembelajarn, Jakarta: PT.Raja Grafindo Persada 
Syah Muhibbin , 2010, Psikologi Belajar, Jakarta Raja Grapindo Persada

Sunarto dan Agung Hartono. 2006, Perkembangan Peserta Didik. Jakarta: Rineka Cipta

Sukardi Dewa Ketut, 2003, Organisasi Administrasi Bimbingan dan Konseling di Sekolah, Surabaya, Usaha Nasional

Sagala Syaiful, 2005, Makna dan Konsep Pembelajaran, Bandung Alfabeta

Surakhmad Winarno, 2005, Manajemen Pembelajaran, Jakarta, Kencana

Suprijono Agus, 2009, Model Pembelajaran Kooperatif, Jakarta, Balai Pustaka

Sudrajat Akhmad, 2008, Strategi Belajar Mengajar. Jakarta: Bina Aksara

Sumantri, 2007, Pendidikan Kewarganegaraan Jakarta: Erlangga 